\title{
Presentasi Ruang Arkeologi Situs Gunung Padang Melalui Visualisasi Batu Penanda Untuk Buku Foto
}

\author{
Winny Gunarti Widya Wardani ${ }^{1}$, Wulandari ${ }^{2}$, Syahid ${ }^{3}$ \\ ${ }^{123}$ Desain Komunikasi Visual, Fakultas Bahasa dan Seni, Universitas Indraprasta PGRI, Jl. Nangka No. 58, \\ Tanjung Barat, Jakarta Selatan 12530, Indonesia \\ ${ }^{1}$ winny.gunartiww@unindra.ac.id
}

\begin{abstract}
Keberadaan batu-batu peninggalan prasejarah di wilayah perbukitan Situs Gunung Padang, Kabupaten Cianjur, telah menempatkan area tersebut sebagai bukti otentik arkeologi. Situs ini pun menjadi sebuah ruang arkeologi, yaitu ruang ilmu tentang masa lalu dan rekonstruksi kebudayaan masyarakatnya di masa itu. Studi ini berpartisipasi untuk mengabadikan nilai penting dari peninggalan situs tersebut, sekaligus membahas elemen-elemen visual yang dapat mempresentasikan ruang arkeologi melalui visualisasi batu penanda untuk buku foto. Metode penelitian kombinasi yang digunakan dalam studi ini melakukan pengumpulan data survei untuk mengetahui pandangan desainer tentang potensi memvisualisasikan area Situs Gunung Padang sebagai ruang arkeologi di dalam buku foto. Data kuantitatif ini kemudian menjadi dasar pembahasan kualitatif tentang presentasi ruang arkeologi dengan menggunakan pendekatan semiotika komunikasi visual, yaitu membaca gambar sebagai tanda, dan maknanya, sehingga visualisasi objek foto dapat dibaca dan membawa pesan. Studi ini mempresentasikan visualisasi batu-batu yang memiliki penanda, yaitu Batu Kujang, Batu Tapak Maung atau Tapak Harimau, Batu Telapak Kaki Manusia, Batu Gamelan, Batu Gendong, dan Batu Singgasana, yang membangun imajinasi tentang aktivitas budaya manusia di masa lalu. Bahasan pembacaan tanda dan makna visualisasi batu mengacu pada tahapan seleksi, pembingkaian, penandaan dan evaluasi, diferensiasi dan koneksi. Hasil studi ini diharapkan dapat menginspirasi masyarakat untuk ikut menghargai dan melestarikan kekayaan arkeologi Indonesia. Pembahasan tentang ruang arkeologi melalui visualisasi batu penanda dalam buku foto juga dapat menjadi referensi ilmiah di bidang fotografi maupun keilmuan desain komunikasi visual.
\end{abstract}

Kata kunci : Presentasi, ruang arkeologi, Gunung Padang, batu penanda, buku foto

\section{Presentation of the Archaeological Space of Gunung Padang Site through the Visual- ization of Signifier Stones For Photobooks}

The story of the existence of prehistoric relics in the hilly area of Gunung Padang Site, Cianjur Regency, has placed the area as authentic archaeological evidence. This site can also be regarded as an archeological space, a space of knowledge about the past and the reconstruction of the culture of its people at that time. This study participates to capture the important values of the site's relics, as well as discuss the visual elements that can present archeological space through visualization of signifier stones in photo books. The combination research method used in this study collected survey data to find out the views of designers about the potential to visualize the Gunung Padang Site area as an archeological space in a photo book. This quantitative data then becomes the basis of qualitative discussion about the presentation of archeological space by using a visual communication semiotic approach to read image as signs and the meaning of image, to produce visualizations of readable and carrying messages. This study presents the visualization of signifier stones, namely Kujang Stone, Maung or Tiger's footprint Stone, Human Foot Stones, Gamelan Stone, Gendong Stone, and Throne Stones, which build imagination about human cultural activities in the past. The discussion of reading signs and meaning of stones visualization refers to the stages of selection, framing, significance and evaluation, differentiation and connection. The results of this study are expected to inspire the community to participate in respecting and preserving Indonesian archaeological wealth. The discussion of archeological space through visualization of signifier stones in photo books can also be a scientific reference in the field of photography and the science of visual communication design.

Keywords : Presentation, archaeological space, Gunung Padang, signifier stones, photobooks 


\section{PENDAHULUAN}

Situs Gunung Padang yang terletak di Desa Karyamukti, Kecamatan Campaka, Kabupaten Cianjur Jawa Barat, telah menjadi perhatian para peneliti mancanegara. Penelitian yang dilakukan oleh Tim Katastropik Purba dari Pemerintah Indonesia pada tahun 2011 menyebutkan bahwa umur lapisan tanah di area yang dipenuhi oleh sebaran batu-batu tersebut berumur kisaran 14.500-25.000 SM. Sampel-sampel tersebut telah diuji di dua tempat, yaitu di Laboratorium Badan Tenaga Nuklir Nasional (BATAN) Jakarta, dan di Laboratorium Beta Analytic Miami, Florida, Amerika Serikat. Temuan ini telah mendorong para peneliti mancanegara untuk melakukan penelitian lanjutan dikarenakan umur sampel bawah permukaan Gunung Padang tersebut jauh lebih tua dari Piramida Giza di Mesir yang berumur 2.500 SM (Akbar, 2014: 4-5).

Fakta jejak prasejarah ini secara tidak langsung telah menjadikan wilayah Situs Gunung Padang sebagai sebuah ruang arkeologi, yaitu ruang ilmu bagi para peneliti maupun wisatawan untuk menguak sejarah peradaban manusia di masa lalu. Bukti otentik arkeologis ini juga menempatkan Situs Gunung Padang sabagai salah satu warisan budaya dunia yang patut dijaga dan dilestarikan. Puncak Gunung Padang yang memiliki ketinggian 989 di bawah permukaan laut, merupakan wilayah perbukitan, dan sebagian masyarakat menyebutnya sebagai Bukit Cahaya. Batu-batu prasejarah yang berundak di area tersebut tersebar ke dalam lima teras yang jaraknya berdekatan, disebut sebagai Teras Satu, Teras Dua, Teras Tiga, Teras Empat, dan Teras Lima. Dalam tulisan Ramadina (2013: 51) disebutkan bahwa Situs Megalitikum terbesar di Asia Tenggara ini memiliki luas 3132,15 meter persegi .

Menurut penelitian yang dilakukan oleh Yondri (2012: 2), batu-batu di Situs Gunung Padang belum dibentuk oleh tangan manusia. Punden berundaknya dibangun dari batuan vulkanik yang berbentuk persegi panjang. Balok-balok batunya berukuran panjang dan berasal dari batuan beku (columnar joint). Akbar (2014: 37) juga menyebutkan bahwa ukuran batu umumnya memiliki panjang sekitar 1,5 meter dengan diameter sekitar 30 sentimeter, dan memiliki lima sisi. Berdasarkan hasil observasi peneliti ke lokasi situs, terlihat ragam batu juga memiliki tampilan yang unik, baik dari bentuk, maupun tekstur dan lekukan-lekukan di permukaannya. Hingga kini, ragam tampilan batu-batu tersebut masih terus diteliti. Sejumlah penelitian menyebutkan bahwa goresan atau lekukan pada batu dapat diartikan sebagai simbol tertentu. Hasil penelitian Yondri (2014: 9) menyimpulkannya sebagai refleksi adaptasi lingkungan dari masyarakat Megalitik, mengingat area punden berundak sangat rawan bencana alam, sehingga diduga masyarakatnya sudah memiliki berbagai pengetahuan dan nilai kearifan untuk menghadapi tantangan bencana alam tersebut.
Tampilan ragam batu di area Situs Gunung Padang menjadi daya tarik tersendiri, terutama dari sudut pandang karya seni fotografi. Objek visual batu dengan aneka goresan dan bentuk sebagai ciri khasnya dapat dilihat sebagai bacaan budaya. Dikatakan Piliang dalam Walker (2010: xxii) tanda di dalam fenomena kebudayaan memiliki cakupan yang luas. Oleh karenanya, selama ada unsur-unsur kebudayaan yang mengandung makna, maka objek tersebut adalah sebuah tanda. Tanda selalu ada dalam kehidupan sosial dan budaya, sehingga pendekatan semiotika menjadi pilihan untuk mengkaji makna tanda.

Oleh karena itu, visualisasi batu-batu prasejarah sebagai penanda berpotensi untuk membawa pesan budaya, khususnya ketika diolah ke dalam desain buku foto sebagai sebuah media yang dapat mempresentasikan ruang arkeologi Situs Gunung Padang. Makna ruang itu sendiri tak dapat dilepaskan dari perjalanan waktu yang menyertainya. Mengacu pada pemikiran Foucault (Barker, 2014: 269) makna ruang dipahami sebagai sebuah konstruksi sosial yang diorganisasikan secara sosial. Dengan kata lain, objek visual batu sebagai penanda di dalam ruang arkeologi dipengaruhi oleh tanda-tanda lain di sekelilingnya sebagai keseluruhan.

Studi ini pun merumuskan pertanyaan penelitian, bagaimana membaca dan memaknai visualisasi batu-batu penanda Situs Gunung Padang sebagai presentasi ruang arkeologi yang membawa pesan budaya di dalam buku foto? Penelitian ini bertujuan untuk ikut mengabadikan peninggalan masa prasejarah dan melestarikan warisan budaya. Sebagai objek visual fotografi, gambar atau foto batu-batu penanda berpotensi untuk menghadirkan kisah kehidupan makhluk hidup di masa lalu, sekaligus mengajak pembacanya untuk berinteraksi dan berimajinasi dengan apa yang dilihatnya.

Selain itu, karya seni fotografi juga termasuk dalam sektor industri kreatif. Pemerintah telah menetapkan 14 subsektor lingkup industri kreatif, meliputi arsitektur, periklanan, barang seni (lukisan, patung), kerajinan, desain, mode atau fesyen, musik, permainan interaktif, seni pertunjukan, penerbitan dan percetakan, layanan komputer dan piranti lunak, radio dan telelisi, riset dan pengembangan, serta film-video dan fotografi (Saryana, dkk., 2018: 155). Penetapan ini secara tidak langsung dapat mendorong penciptaan karya seni fotografi yang kompetitif dan berskala global.

\section{METODE PENELITIAN}

Studi ini menggunakan metode kombinasi untuk mengumpulkan dan menganalisis data kuantitatif dan kualitatif. Sebagai pendahuluan, penelitian ini melakukan survei terhadap mahasiswa desain komunikasi visual di lingkungan Universitas Indraprasta PGRI, dengan sampel mahasiswa pada mata kuliah fotografi, untuk mengetahui pandangan 
mereka tentang potensi visual dari objek fotografi di area Situs Gunung Padang sebagai bagian dari daya tarik visual buku foto. Hasil data kuantitatif ini menjadi dasar analisis kualitatif dengan menggunakan pendekatan semiotika komunikasi visual, khususnya dalam membaca elemen visual sebagai tanda.

Dikatakan Saussure (dalam Fiske, 2007:65) tanda adalah objek fisik dengan sebuah makna yang terdiri atas penanda (signifier), yaitu citra tanda yang dipersepsikan. Dalam hal ini, penanda dilihat sebagai apa yang ditampilkannya. Sedangkan petanda (signified) adalah kerangka konsep dan makna, sebagai acuan secara luas dari semua anggota kebudayaan dengan menggunakan bahasa yang sama. Proses ketika tanda menghasilkan makna disebut signifikasi atau pemaknaan.

Adapun pembahasan terhadap karya seni fotografi sebagai sebuah gambar/foto dalam presentasi ruang arkeologi untuk batu-batu penanda mengacu pada analisis (Schirato \& Webb, 2004: 62-64):

1. Gambar sebagai tanda, yaitu segala hal yang hadir atau ada untuk sesuatu.

2. Gambar dan makna, yaitu gambar dengan tanda-tanda visual yang bekerja secara analogis, di mana makna dihasilkan melalui kombinasi elemen-elemen internal dan ekternal.

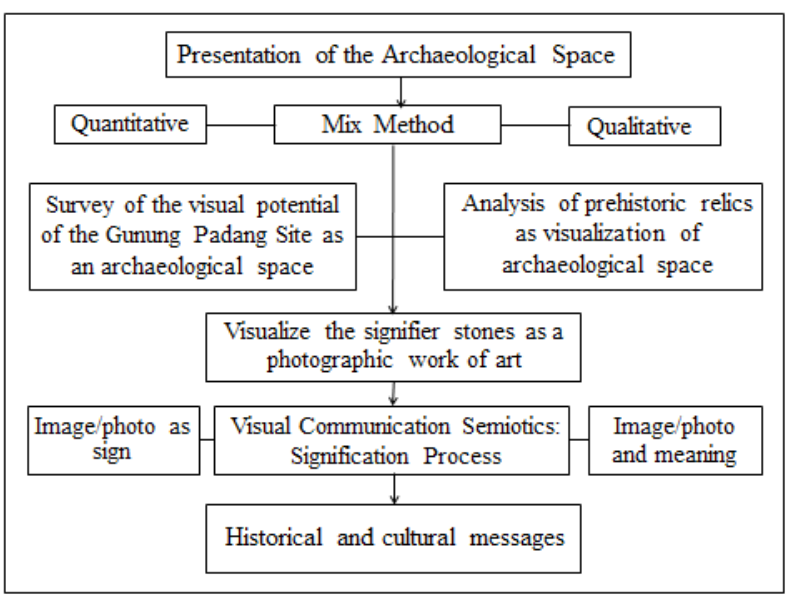

Gambar 1. Analysis Model

Visualisasi batu-batu penanda sebagai karya seni fotografi yang dianalisis dalam studi ini meliputi enam objek batu, yaitu: Batu Kujang, Batu Tapak Maung atau Tapak Harimau, Batu Telapak Kaki Manusia, Batu Gamelan, Batu Gendong, dan Batu Singgasana. Pilihan terhadap keenam objek batu tersebut didasarkan pada hasil observasi peneliti di area Situs Gunung Padang, sebagai batu-batu yang banyak dicermati oleh para wisatawan maupun peneliti, sesuai dengan arahan para pengelola situs selaku pemandu wisata.

\section{PEMBAHASAN}

Perolehan data kuantitatif dalam studi ini meliputi potensi area Situs Gunung Padang sebagai ruang arkeologi di dalam buku foto, khususnya sebagai daya tarik visual untuk edukasi sejarah dan budaya, serta kekuatan visual dari ragam batu yang ada di wilayah tersebut. Untuk itu dilakukan survei terhadap responden mayor, yaitu 175 mahasiswa desain yang memang memiliki pengetahuan tentang Situs Gunung Padang, dengan menggunakan skala Guttman. Perihal pandangan tentang potensi memvisualisasikan peninggalan prasejarah Situs Gunung Padang ke dalam buku foto, data kuantitatif menunjukkan bahwa 125 (72\%) mahasiswa menyatakan "ya", sedangkan sebanyak 4 (2\%) mahasiswa menyatakan "tidak", dan 46 (26\%) mahasiswa menyatakan "tidak tahu". Persentase data tersebut menjadi acuan untuk mendesain buku foto yang mengangkat objek benda-benda prasejarah sebagai bagian dari daya tarik ruang arkeologi Situs Gunung Padang.

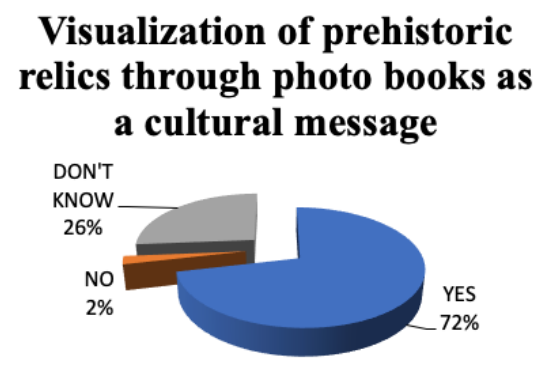

Gambar 2. The Potential of Visualization of Prehistoric Relics Through Photo Books

Sedangkan perihal pandangan tentang daya tarik dari ragam batu sebagai kekuatan visual dari ruang arkeologi Situs Gunung Padang menunjukkan bahwa sebanyak 57 (33\%) mahasiswa menyatakan "ya" terhadap potensi visual batu-batu peninggalan prasejarah tersebut, kemudian sebanyak 16 (9\%) mahasiswa menyatakan "tidak", dan 102 (58\%) mahasiswa menyatakan "tidak tahu". Persentase kuantitatif yang menunjukkan tingginya ketidaktahuan tentang daya tarik visual objek batu, dapat mempertajam analisis kualitatif mengenai potensi batu-batu penanda yang dijadikan karya seni fotografi.

\section{The attraction of Gunung Padang Site is found in various stones as visual object}

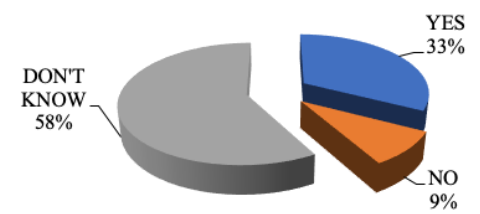

Gambar 3. Various Stones as Visual Object 
Berdasarkan hasil wawancara peneliti dengan beberapa mahasiswa dari sampel responden tersebut, mereka menganggap bahwa unsur pemandangan dari area Situs Gunung Padang lebih menarik dibandingkan benda mati. Rendahnya pemahaman responden tentang potensi objek batu sebagai kekuatan visual dalam buku foto dapat dijadikan pembahasan. Di dalam genre fotografi, untuk menjadikan benda mati menjadi gambar yang "hidup" disebut sebagai still life. Objek benda mati dapat dikonstruksi untuk dapat membawa pesan sesuai dengan target yang ingin dicapai.

Namun, pembahasan tentang batu-batu penanda pada studi ini lebih dikhususkan pada proses pemaknaannya sebagai tanda visual di dalam presentasi ruang arkeologi. Karya seni fotografi erat kaitannya dengan ilmu tentang tanda. Fotografi adalah proses dan seni menghasilkan gambar melalui cahaya pada film dengan memperhatikan unsur-unsur penting dari pencahayaan, warna, dan komposisinya (Hidayat dan Arumsari, 2017: 597). Mengkomunikasikan pesan di dalam karya seni fotografi di dalam buku foto berarti membaca dan mengolah elemen-elemen visual yang membentuk objek sebagai sebuah rangkaian yang memiliki narasi.

Studi ini melakukan empat tahapan dalam proses pemilihan dan pengolahan objek batu-batu penanda di area Situs Gunung Padang.

Tahap seleksi, yaitu tahap menyeleksi objek foto, dalam hal ini adalah pilihan terhadap batu-batu penanda. Studi ini memilih enam objek batu penanda sesuai hasil observasi dan arahan dari pengelola Situs Gunung Padang, sebagai batu-batu yang memiliki pesan budaya. Batu-batu penanda tersebut adalah (Akbar, 2014: 27-39):

a. Batu Kujang, sebuah batu penanda yang permukaannya memiliki tanda berupa goresan menyerupai senjata khas Jawa Barat, yaitu senjata Kujang. Goresan ini terdapat di beberapa batu dan diartikan sebagai simbol tertentu oleh masyarakat.

b. Batu Tapak Maung atau Tapak Harimau, sebuah batu penanda yang permukaannya memiliki tanda berupa lekukan menyerupai tapak kaki harimau.

c. Batu Telapak Kaki Manusia, sebuah batu penanda yang permukaannya memiliki tanda berupa lengkungan dalam menyerupai telapak kaki manusia dalam ukuran yang besar, dua kali dari telapak kaki manusia yang umum saat ini.

d. Batu Gamelan, sebuah batu penanda yang berbentuk memanjang dan memantulkan bunyi menyerupai suara gamelan apabila dipukul.

e. Batu Gendong, sebuah batu penanda berbentuk balok yang terletak di atas permukaan tanah, tidak tertancap, namun sulit untuk diangkat atau digerakkan karena berat.

f. Batu Singgasana, sebuah batu penanda yang berbentuk balok dengan permukaan melebar menyerupai dudukan, dan dianggap sebagai tempat duduk para raja di masa itu.

Tahap pembingkaian, yaitu tahap memasukkan pilihan objek visual ke dalam bingkai (frame), berupa penetapan pembingkaian (framing) terhadap batu-batu penanda. Pembingkaian dapat menerapkan aturan sepertiga (rule of thirds), yaitu menempatkan objek visual sebagai pusat perhatian dalam komposisi yang baik. Pembingkaian dilakukan dengan membagi bidang gambar menjadi sepertiga bagian sama besar dan membuat dua garis secara vertikal dan horizontal. Kemudian objek visual ditempatkan pada titik perpotongan garis-garis tersebut. Bisa ditempatkan pada tepi kiri, tepi kanan, atau tepi atas dan bawah sebagai pusat (Herlina, 2007: 84). Tahap pembingkaian ini juga mempertimbangkan sudut pengambilan gambar dan fokus objek sesuai dengan konteksnya. Penerapan aturan sepertiga dapat dilihat pada gambar berikut.

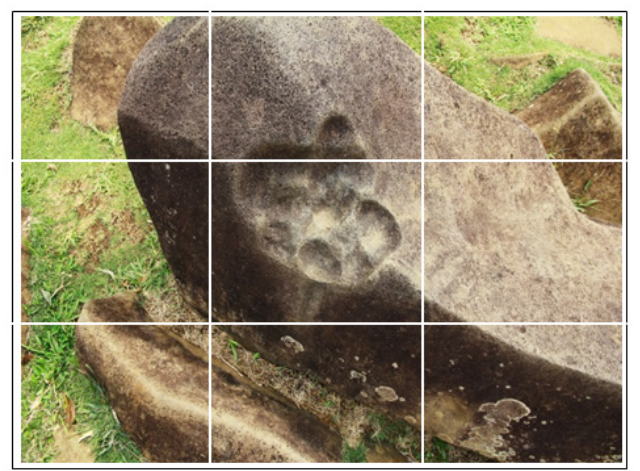

Gambar 4. Rule of Thirds of Visual Object

Tahap penandaan dan evaluasi, yaitu tahap menjelaskan representasi dari objek visual batu-batu yang dipilih, berupa tahapan pembacaan elemen visual sebagai penanda dan petanda. Pada tahapan ini, peneliti membagi keenam batu-batu penanda ke dalam dua kategori, yaitu kategori visualisasi batu dengan pembacaan dan pemaknaan tanda pada permukaan batu, dan kategori visualisasi batu dengan pembacaan dan pemaknaan pada bentuk batu. Pembagian kategori tersebut dapat dilihat pada gambar berikut.

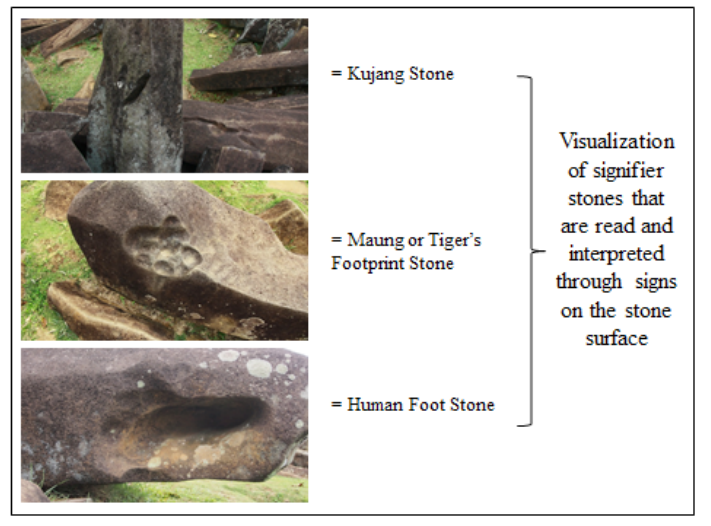

Gambar 5. Signifier Stones that are read and interpreted through signs on the stone surface 


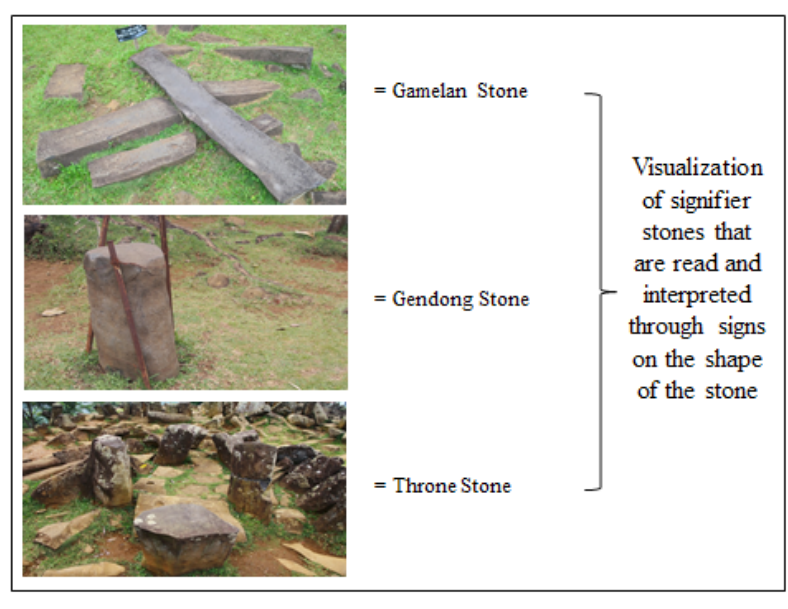

Gambar 6. Signifier Stones that are read and interpreted through signs on the shape of the stone

Tahap diferensiasi dan koneksi, yaitu tahap memfungsikan elemen visual sebagai pembawa pesan, di mana tanda-tanda visual pada batu-batu penanda menjadi bermakna. Pemahaman elemen tanda pada objek visual menurut Barthes (dalam Pratama, dkk., 2017: 296) dapat ditelaah sesuai dengan makna informasi, makna simbolik, dan makna gambar.

Dalam konteks batu-batu penanda, maka tahap diferensiasi dan koneksi dapat mengacu pada ketiga pemaknaan di atas, yaitu:

a. Makna informasi, pemaknaan dengan cara melihat latar belakang dari keberadaan batu-batu penanda, yang dikaitkan dengan kehidupan masyarakat dan budayanya.

b. Makna simbolik, pemaknaan dengan cara memahami simbol-simbol yang telah menjadi konvensi di masyarakat.

c. Makna gambar, pemaknaan dengan cara menginterpretasikan tanda visual yang ada berdasarkan kedua pemaknaan sebelumnya.

Berdasarkan kategori visualisasi batu-batu penanda, pemaknaan dapat dijelaskan sebagai berikut:

1) Visualisasi yang dibaca dan dimaknai melalui tanda pada permukaan batu

\section{Batu Kujang}

Goresan pada permukaan batu yang menyerupai bentuk senjata khas Jawa Barat, dimaknai oleh masyarakat sebagai simbol Kujang. Latar belakang keberadaan Kujang itu sendiri masih terus menjadi penelitian. Kajian historis dan filosofis oleh Kurniawan (2014: 30) menyebutkan jumlah lubang 1 pada bilah Kujang adalah simbol letak Kota Praja yang disebut Sunda tahun 670 M, ketika kerajaan Tarumanegara dipimpin oleh Maharaja Purnawarman. Di zaman Padjadjaran Mangukuhan, Kujang menjadi pusaka lambang pemersatu Sundapura dan Galuh pada tahun 739
M. Berdasarkan makna informasi dan makna simbolik ini, Batu Kujang sebagai penanda dapat diinterpretasikan membawa pesan tentang kemungkinan jejak asal mula keberadaan senjata Kujang.

\section{Batu Tapak Maung atau Tapak Harimau}

Lekukan-lekukan pada permukaan batu yang menyerupai tapak kaki harimau, dimaknai oleh masyarakat sebagai simbol cakar raja hutan. Di dalam kebudayaan Jawa Barat, harimau menjadi hewan yang memiliki kesaktian. Akbar (2014: 38) menjelaskan bahwa anggapan masyarakat tersebut didasarkan pada kepercayaan, bahwa anak dari Prabu Siliwangi yang bernama Prabu Kiansantang pernah menjelajah masuk hutan demi mencari ayahnya yang pergi dari istana dan konon menjelma menjadi maung atau harimau. Dari makna informasi dan simbolik ini, maka Batu Tapak Harimau sebagai penanda dapat diinterpretasikan membawa pesan tentang sebuah tradisi lisan yang diwariskan secara turun-temurun perihal wujud Prabu Siliwangi.

\section{Batu Telapak Kaki Manusia}

Batu penanda ini memiliki lekukan yang cukup besar dan dalam pada permukaannya dan dimaknai sebagai simbol telapak kaki manusia prasejarah. Manusia purba adalah manusia yang hidup dengan peralatan batu dan belum mengenal tulisan. Manusia purba di Situs Gunung Padang adalah manusia purba zaman Megalitikum, karena ditemukan di area punden berundak, sebuah bangunan tempat pemujaan awah yang bertingkat-tingkat sebagai salah satu ciri zaman ini. Manusia purba digambarkan tinggi besar dan kuat. Studi magnetostratigrafi yang dilakukan oleh Setyanta, dkk. (2014: 11), yaitu ilmu yang mempelajari fosil kemagnetan dan terekam dalam batuan, menyebutkan manusia purba tertua ditemukan di Jawa di wilayah Sangiran, dan yang termuda di Patiayam. Sesuai dengan makna informasi dan simbolik ini, maka pemaknaan terhadap visualisasi batu penanda berupa lekukan dalam dan lengkungan menyerupai jari-jari kaki tersebut diinterpretasikan sebagai jejak telapak kaki manusia purba.

2) Visualisasi yang dibaca dan dimaknai melalui tanda pada bentuk batu

\section{Batu Gamelan}

Bentuk Batu Gamelan yang memanjang dimaknai secara simbolik sebagai bentuk alat musik yang biasa digunakan dalam kesenian. Informasi tentang bentuk batu penanda ini pernah dituturkan Bintarti pada tahun 1981 (dalam Akbar, 2014: 34), bahwa orang-orang yang menyukai kesenian dulunya banyak datang ke Gunung Padang sambil membawa kemenyan dan bunga, dengan harapan mereka dapat menjadi seniman sukses. Masyarakat sekitar sering mendengar suara gamelan, wayang, dan suara kecapi, terutama pada malam Senin dan Rabu. Hingga kini, beberapa batu di Gunung Padang kerap dijadikan alat musik oleh pengunjung karena mengeluarkan bunyi tertentu apabila dipukulkan. Makna informasi dan simbolik ini memban- 
Tabel 1. Visualization of Signifier Stones and Meaning

\begin{tabular}{ll}
\multicolumn{1}{c}{ Visualization } & \multicolumn{1}{c}{ Signifier (Signs Reading) } \\
\hline \\
$\begin{array}{l}\text { Signifier stones that Kujang Stone } \\
\text { are read and interpret- } \\
\text { ed through signs on the } \\
\text { stone surface }\end{array}$ & $\begin{array}{l}\text { Presentation of the archaeological space } \\
\text { about the origin of Kujang's weapon exis- } \\
\text { tence }\end{array}$ \\
\cline { 2 - 2 }
\end{tabular}

$\begin{aligned} \text { Maung or Tiger's Footprint Stone } & \text { Presentation of the archaeological space } \\ & \text { about oral tradition regarding the figure of } \\ & \text { Prabu Siliwangi which continues to be de- } \\ & \text { bated }\end{aligned}$
about oral tradition regarding the figure of bated

Human Foot Stone

Presentation of the archaeological space about ancient human feet and a picture of life and civilization

Signifier stones that Gamelan Stone

Presentation of the archaeological space are read and interpreted through signs on the about $n$ overview of past artistic traditions shape of the stone that made stone a musical instrument

Gendong Stone

Presentation of the archaeological space about mythical things that are occult, considering the area of Gunung Padang as a place to meditate and worship ancestors

Throne Stone

Presentation of the archaeological space about the glory and great influence of the Kingdom of Padjadjaran

gun makna interpretasi tentang visualisasi Batu Gamelan yang bukan sekadar alat musik, melainkan mampu membangun imajinasi tentang sebuah tradisi kesenian di masa lalu.

\section{Batu Gendong}

Bentuk Batu Gendong menyerupai batu balok yang tebal. Batu ini tidak tertancap di tanah dan berat, sehingga tidak sembarang orang dapat memindahkannya. Batu ini dimaknai secara simbolik sebagai batu penanda terkabulnya doa apabila bisa digendong. Batu Gendong berada di semacam ruangan terbuka yang dikelilingi batu-batu columnar joint berbentuk segiempat. Para pengunjung yang datang ke Gunung Padang biasanya ingin mencoba mengangkat batu tersebut. Keyakinan terhadap Batu Gendong sebagai dtanda bahwa doanya akan dikabulkan oleh Tuhan dilatari kepercayaan masyarakat yang mengacu pada mitos. Ber- tahan mitos di masyarakat meskipun zaman telah modern, menurut Brunvand dalam Danandjaja (1986, dalam Rachman, dkk., 2008: 1-2) karena adanya cara berpikir yang salah, koinsidensi, kegemaran untuk percaya pada yang gaib, kebutuhan untuk bertahan hidup, perasaan tidak tentu terhadap tujuan dambaannya, ketakutan akan sesuatu yang tidak normal, takut akan kematian, upaya memodernisasi pikiran takhayul, dan adanya kepercayaan untuk tetap hidup berdampingan antara yang gaib dan ilmu agama. Pemahaman tentang makna informnasi dan simbolik terhadap Batu Gendong pada dasarnya tidak memiliki koneksi yang signifikan, karena Batu Gendong sama seperti batu-batu di sekitarnya. Interpretasi terhadap Batu Gendong lebih mengarah pada mitos tentang hal-hal yang gaib, karena area Gunung Padang dulunya adalah tempat pemujaan arwah. 


\section{Batu Singgasana}

Bentuk Batu Singgasana ini menyerupai dudukan dengan permukaan batu yang lebar, dengan di sisi kiri kanannya terdapat batu-batu balok yang berjajar. Batu Singgasana dimaknai secara simbolik oleh masyarakat sebagai tempat semedi Prabu Siliwangi, seorang Raja Kerajaan Padjadjaran yang dipercaya memerintah pada Abad ke-14 dan ke-15 Masehi. Penyebutan singgasana menurut Akbar (2014: 32) karena adanya keyakinan bahwa Istana Kerajaan Padjadjaran terletak di Gunung Padang. Masyarakat setempat juga percaya bahwa Batu Singgasana dapat digunakan untuk duduk berdoa, menenangkan diri, bahkan bisa meningkatkan pangkat dan kedudukan seseorang. Makna informasi dan simbolik tersebut secara tidak langsung membangun interpretasi tentang kejayaan dan pengaruh dari pemerintah Kerajaan Padjadjaran pada masa itu.

Secara garis besar, analisis visualisasi keenam batu penanda di atas sebagai daya tarik dari presentasi ruang arkeologi yang dapat dibaca dan dimaknai melalui buku foto dapat dirumuskan dalam tabel 1.

Demikian keseluruhan pembahasan tentang pemaknaan pada visualisasi batu-batu penanda untuk buku foto sebagai sebuah presentasi ruang arkeologi Situs Gunung Padang yang membawa pesan budaya dan dapat membangun inspirasi edukasi tentang sejarah kehidupan manusia dengan alam lingkungannya di masa lalu.

\section{SIMPULAN}

Studi ini menghasilkan visualisasi batu-batu penanda untuk ditampilkan dalam buku foto sebagai sebuah karya seni fotografi tentang Situs Prasejarah Gunung Padang. Enam objek batu penanda sebagai referensi dari presentasi ruang arkeologi tersebut dapat membawa pesan tentang keberadaan makhluk hidup di masa lalu. Sebutan terhadap Batu Kujang sebagai batu penanda menunjukkan visualisasi senjata khas Jawa Barat yang masih terus diteliti sejarahnya. Kemudian Batu Tapak Maung atau Batu Tapak Harimau sebagai batu penanda, membangun persepsi tentang keberadaan hewan harimau yang di dalam tradisi Sunda dipercaya sebagai jelmaan Prabu Siliwangi. Selanjutnya Batu Telapak Kaki Manusia sebagai batu penanda juga memberi gambaran tentang sosok manusia prasejarah di zaman Megalitikum. Lalu Batu Gamelan sebagai batu penanda menjadi presentasi adanya kebudayaan kesenian dengan menggunakan alat musik batu yang mampu mengeluarkan bunyi seperti gamelan. Batu Gendong sebagai batu penanda, divisualisasikan sebagai batu yang tidak tertancap di tanah, namun sulit untuk diangkat sehingga membangun kepercayaan tertentu di masyarakat. Sedangkan Batu Singgasana sebagai batu penanda, mempresentasikan tentang ruang semedi atau pertapaan Prabu Siliwangi.
Keseluruhan presentasi batu penanda tersebut dapat menjadi bagian dari visualisasi ruang arkeologi di dalam buku foto, sebagai daya tarik visual, sekaligus menginspirasi para peneliti untuk menemukan jejak kebudayaan masyarakat di masa silam. Pembacaan elemen-elemen visual terhadap batu penanda di dalam prinsip fotografi dapat diterapkan dengan pendekatan semiotika komunikasi visual, di mana gambar atau foto dilihat dan dibaca sebagai tanda, kemudian gambar atau foto dan maknanya, dengan melakukan tahapan seleksi, pembingkaian, penandaan dan evaluasi, diferensiasi dan koneksi sesuai konteksnya.

Studi tentang presentasi ruang arkeologi Situs Gunung Padang ini diharapkan dapat mendorong karya seni fotografi lain, khususnya tentang visualisasi benda-benda mati yang memiliki penanda dan membawa pesan budaya. Sebagai sebuah karya seni, kajian fotografi juga menjadi pilihan kreativitas yang kompetitif di bidang industri kreatif. Hasil studi ini juga dapat mendorong masyarakat secara umum, kreator, maupun seniman fotografi untuk mengabadikan benda-benda purba yang banyak terdapat di berbagai situs di Indonesia, sebagai bentuk penghargaan dan upaya menjaga kelestarian kekayaan arkeologi Indonesia. Pembahasan ruang arkeologi melalui visualisasi batu penanda yang ditampilkan dalam buku foto juga dapat menjadi referensi ilmiah di lingkungan akademis.

\section{UCAPAN TERIMA KASIH}

Penghargaan dan terima kasih kepada Direktorat Riset dan Pengabdian Masyarakat, Dirjen Penguatan Riset dan Pengembangan, Kementerian Riset, Teknologi dan Pendidikan Tinggi dan yang telah membiayai kegiatan Penelitian Dasar Unggulan Perguruan Tinggi (PDUPT) Tahun 2019 dengan judul: "Perancangan buku foto situs Megalitikum Gunung Padang dengan genre still life, landscape, dan story sebagai upaya melestarikan warisan sejarah dan budaya di Desa Karyamukti Cianjur". Terima kasih juga kepada LLDIKTI Wilayah III Jakarta dan Lembaga Penelitian dan Pengabdian Masyarakat Universitas Indraprasta PGRI yang telah membantu kegiatan penelitian ini melalui Kontrak Penelitian: Nomor: 16/AKM/PNT/2019, Tanggal 27 Maret 2019.

\section{DAFTAR RUJUKAN}

Akbar, A. (2014). Situs Gunung Padang, Misteri dan Arkeologi. Jakarta: Change Publication.

Barker, C. (2014). Kamus Kajian Budaya. Yogyakarta: Penerbit PT. Kanisius

Fiske, J. (2007). Cultural and Communication Studies, Sebuah Pengantar Paling Komprehensif. Yogyakarta: Jalasutra. 
Herlina, Y. (2007). Komposisi Dalam Seni Fotografi. NIRMANA, Vol.9, No. 2, Juli 2007, 82-88.

Hidayat, M. F., dan Arumsari, R. Y. (2017). "Perancangan Buku Photo Story". e-Proceeding of Art \& Design, 4 (3), Desember 2017, 596-603.

Kurniawan, A. (2014). Kajian Historis dan Filosofis Kujang. Jurnal Itenas Rekarupa, Vol 2 No. 1, Januari-Juni 2014, 29-40.

Pratama, D., Wardani,W. G. W., Akbar, T. (2017). Understanding Visual Novel as Artwork of Visual Communication Design. MUDRA Journal of Art and Culture, Volume 32 Nomor 3, September 2017, 292-298

Rachman, D., Pratiwi, Y., Roekhan (2008). Kajian Mitos Masyarakat Terhadap Folklor Ki Ageng Gribig. Universitas Negeri Malang, diunduh dari http://jurnal-online.um.ac. id/data/artikel/artikelE3EBA269204A2171BFA96FD95DA8CB60.pdf, 1-10.

Ramadina, S. P. (2013). “Analisis Perupaan Situs Megalitik Gunung Padang di Cianjur, Jawa Barat”. Fakultas Seni Rupa dan Desain. Institut Teknologi Bandung. J. Vis. Art \& Des, 4 (1), 51-66.

Saryana, I M., Raharjo, A., Octaviano, A. L. (2018). Desain Ilustrasi Foto Pada Baju Kaos Dengan Media Fotografi Digital Pendukung Pariwisata Budaya Di Pura Tanah Lot Dan Taman Ayun. MUDRA Jurnal Seni Budaya, Volume 33, Nomor 1, Februari 2018 p $154-160$

Schirato, T. \& Webb, J. (2004). Reading the Visual. Alen \& Unwin, Crows-Nest.

Setyanta, B., Siagian, H. P., dan Wahyono, H. (2014). Penentuan Umur Fosil Manusia Purba di Jawa Berdasarkan Magnetostratigrafi. J.G.S.M. Vol. 15 No. 1 Februari 2014, $11-24$.

Walker, J. A. (2010). Desain, Sejarah, dan Budaya, Sebuah Pengantar Komprehensif. Yogyakarta: Jalasutra.

Yondri, L. (2014). Punden Berundak Gunung Padang "Refleksi Adaftasi Lingkungan dari Masyarakat Megalitik". Fakultas Ilmu Budaya. Universitas Padjadjaran Bandung. Jurnal Sosioteknologi, 13 (1), 1-14.

Yondri, L. (2012). Punden Berundak Gunung Padang Maha Karya Nenek Moyang dan Kandungannya akan Nilai-nilai Kearifan Lingkungan di Masa Lalu di Tatar Sunda. Laporan penelitian Balai Arkeologi Bandung, 1-16. 